\title{
Chemical Composition and Antibacterial Activity of the Essential Oil of Vitex agnus-castus L. (Lamiaceae)
}

\author{
REGIANE GONÇALVES ${ }^{1}$, VANESSA F.S. AYRES ${ }^{1}$, CARLOS E. CARVALHO ${ }^{1}$, MARIA \\ G.M. SOUZA ${ }^{2}$, ANDERSON C. GUIMARÃES ${ }^{1}$, GEONE M. CORRÊA ${ }^{1}$, CARLOS H.G. \\ MARTINS $^{2}$, RENATA TAKEARA ${ }^{1}$, ELIANE O. SILVA ${ }^{3}$ and ANTÔNIO E.M. CROTTI ${ }^{4}$ \\ ${ }^{1}$ Instituto de Ciências Exatas e Tecnológicas, Universidade Federal do Amazonas, Rua Nossa \\ Senhora do Rosário, 3863, Tiradentes, 69103-128 Itacotiara, AM, Brazil \\ ${ }^{2}$ Núcleo de Pesquisas em Ciências Exatas e Tecnológicas, Universidade de Franca, Av. Dr. \\ Armando Salles de Oliveira, 201, Parque Universitário, 14404-600 Franca, SP, Brazil \\ ${ }^{3}$ Departamento de Química Orgânica, Instituto de Química, Universidade Federal da Bahia, \\ Rua Barão de Jeremoabo, s/n, Ondina, 40170-115 Salvador, BA, Brazil \\ ${ }^{4}$ Departamento de Química, Faculdade de Filosofia, Ciências e Letras de Ribeirão Preto, Universidade \\ de São Paulo, Av. Bandeirantes, 3900, Monte Alegre, 14040-901 Ribeirão Preto, SP, Brazil
}

Manuscript received on June 2, 2017; accepted for publication on August 7, 2017

\begin{abstract}
Abnormal multiplication of oral bacteria causes dental caries and dental plaque. These diseases continue to be major public health concerns worldwide, mainly in developing countries. In this study, the chemical composition and antimicrobial activity of the essential oil of Vitex agnus-castus leaves (VAC-EO) collected in the North of Brazil against a representative panel of cariogenic bacteria were investigated. The antimicrobial activity of VAC-EO was evaluated in terms of its minimum inhibitory concentration (MIC) values by using the broth microdilution method in 96-well microplates. The chemical constituents of VAC-EO were identified by gas chromatography (GC-FID) and gas chromatography-mass spectrometry (GC-MS). VAC-EO displayed some activity against all the investigated oral pathogens; MIC values ranged from 15.6 to $200 \mu \mathrm{g} / \mathrm{mL}$. VAC-EO had promising activity against Streptococcus mutans (MIC= $15.6 \mu \mathrm{g} / \mathrm{mL})$, Lactobacillus casei $(\mathrm{MIC}=15.6 \mu \mathrm{g} / \mathrm{mL}$ ), and Streptococcus mitis $(\mathrm{MIC}=31.2 \mu \mathrm{g} / \mathrm{mL})$. The compounds 1,8-cineole (23.8\%), (E)- $\beta$-farnesene (14.6\%), (E)-caryophyllene $(12.5 \%)$, sabinene $(11.4 \%)$, and $\alpha$-terpinyl acetate $(7.7 \%)$ were the major chemical constituents of VAC-EO. VAC-EO displays antimicrobial activity against cariogenic bacteria. The efficacy of VAC-EO against $S$. mutans is noteworthy and should be further investigated.
\end{abstract}

Key words: Streptococcus mutans, 1-8-cineole, cariogenic bacteria, oral pathogens.

\section{INTRODUCTION}

Acidogenic and aciduric bacteria that can form colonies in an organized biolfilm cause dental plaque

Correspondence to: Antônio Eduardo Miller Crotti

E-mail: millercrotti@ffclrp.usp.br
(Crevelin et al. 2015). Brushing and flossing are the most effective strategies to remove microorganisms installed on the tooth surface and hence prevent caries and gum diseases. Controlling the formation of biofilm and completely removing the biofilm through mechanical means is complicated, and most of the 
population fails to ensure proper oral care (Melo et al. 2015). Some products containing antimicrobial agents have been used as a complementary measure to help to decrease the formation of biofilm on the tooth surface (Crevelin et al. 2015). Chlorhexidine has been widely applied for this purpose because it displays anticariogenic properties. However, its regular use in oral care products often leads to several side effects and contributes to the emergence of microbial resistance (Aguiar et al. 2013a).

Vitex agnus-castus L. (Lamiaceae) is a small tree or shrub native to European, Mediterranean, and Central Asian countries. In Brazil, European immigrants introduced $V$. agnus-castus into the Amazon region (Zoghbi et al. 1999). This plant has well-known biological potential. Its diuretic, antiseptic, digestive, antifungal, antianxiety, aphrodisiac, anti-estrus, emmenagogus, antispasmodic, aperitif, and analgesic effects have been applied in folk medicine. V. agnus-castus has also been employed to treat mastopathies, to inhibit dopamine D2 and opioid receptors, and to inhibit the synthesis of prolactin, among other uses (Zahid et al. 2016). Moreover, this species is one of the most traditional and effective medicinal plants to be used in the relief of uterine cramps and in the regulation of menstruation (Gurmeet and Chhabra 2011, Mari et al. 2012). The essential oil (EO) extracted from the seeds of $V$. agnus-castus presents antimicrobial activity against Candida species that cause nosocomial infections (Asdadi et al. 2015), whereas the EO extracted from the leaves of this same plant species acts against some important plant pathogens such as Agrobacterium tumefaciens, Erwinia carotovora var. carotovora, Alternaria alternata, Botrytis cinerea, Fusarium oxysporum, and Fusarium solani (Badawy and Abdelgaleil 2014). The EO extracted from the fruits and leaves of $V$. agnus-castus exerts activity against Salmonella typhimurium and Micrococcus flavus (Stojković et al. 2011). However, the antimicrobial activity of the EO of $V$. agnus-castus against oral pathogens has not been investigated yet.

As part of our ongoing project on the antimicrobial activity of essential oils (Aguiar et al. 2013a, Alves et al. 2015, Bardaji et al. 2015, Crevelin et al. 2015, Melo et al. 2015), we have investigated the chemical constituents and the antimicrobial activity of the EO of Vitex agnuscastus grown in the North of Brazil against a representative panel of cariogenic bacteria.

\section{MATERIALS AND METHODS}

\section{PLANT MATERIAL}

Vitex agnus-castus L. (Lamiaceae) was collected near the city of Itacotiara (58 $26^{\prime} 54.3^{\prime}$ 'S $\left.3^{\circ} 8^{\prime} 28.8^{\prime \prime} \mathrm{W}\right)$, state of Amazonas, Brazil in June 2009 and identified by Prof. Ari de Freitas Hidalgo (Universidade Federal do Amazonas, Brazil). A voucher specimen (HUAM 8268) was deposited at the Herbarium of Universidade Federal do Amazonas, Manaus, Brazil (Herbarium UFAM).

\section{EXTRACTION OF THE ESSENTIAL OIL}

Fresh $V$. agnus-castus leaves $(1,500 \mathrm{~g})$ were submitted to hydrodistillation in a Clevenger-type apparatus for $3 \mathrm{~h}$. Before the extraction, the plant material was divided into three samples of $500 \mathrm{~g}$ each, and 500 $\mathrm{mL}$ of distilled water had been added to each sample. The essential oil of $V$. agnus-castus (VAC-EO) was manually collected, and traces of water were removed by addition of anhydrous sodium sulfate. After filtration, VAC-EO was stored at $4{ }^{\circ} \mathrm{C}$, in the dark, until analysis. The yield (w/w) of VAC-EO was calculated from the weight of the fresh leaves and expressed as the average of triplicate analysis.

GAS CHROMATOGRAPHY (GC) AND GAS CHROMATOGRAPHY-MASS SPECTROMETRY (GCMS) ANALYSES

The chemical constituents of VAC-EO were identified using previously published methodology 
(Tonuci et al. 2012, Aguiar et al. 2013b, Baldin et al. 2015, Melo et al. 2015, Wakabayashi et al. 2015, Vieira et al. 2017). To this end, ethyl ether was used as solvent, and the samples were analyzed on a Shimadzu GC2010 Plus gas chromatograph equipped with an AOC-20s autosampler and fitted with FID and a data-handling processor. An Rtx5 (Restek Co., Bellefonte, PA, USA) fused silica capillary column (30 m x 0.25-mm i.d.; $0.25 \mu \mathrm{m}$ film thickness) was employed. The temperature of the column was programmed to rise from 60 to $240{ }^{\circ} \mathrm{C}$ at $3{ }^{\circ} \mathrm{C} / \mathrm{min}$ and was then held at 240 ${ }^{\circ} \mathrm{C}$ for $5 \mathrm{~min}$. Helium (99.999\%) at a flow rate of $1.0 \mathrm{~mL} / \mathrm{min}$ was used as carrier gas. The injected sample volume was $0.1 \mu \mathrm{L}$ (split ratio of $1: 10$ ), and the temperatures of the injector and the detector were 240 and $280{ }^{\circ} \mathrm{C}$, respectively. The relative concentrations of the chemical components of VAC-EO were obtained by normalization of the peak areas (\%). The relative areas were the average of triplicate GC-FID analyses.

A Shimadzu QP2010 Plus (Shimadzu Corporation, Kyoto, Japan) system equipped with an AOC-20i autosampler was used during the GCMS analyses. The Rtx-5MS (Restek Co., Bellefonte, PA, USA) fused silica capillary column $(30 \mathrm{~m}$ length $\times 0.25 \mathrm{~mm}$ i.d. $\times 0.25 \mu \mathrm{m}$ film thickness) was employed for the analyses. The electron ionization mode was used at $70 \mathrm{eV}$. The carrier gas was helium $(99.999 \%)$ at a flow rate of $1.0 \mathrm{~mL} / \mathrm{min}$, and the injection volume was $0.1 \mu \mathrm{L}$ (split ratio of $1: 10)$. The temperatures of the injector and the ion source were set at 240 and $280{ }^{\circ} \mathrm{C}$, respectively. The oven temperature program was the same as the one used for GC-FID. The mass spectra were taken with a scan interval of $0.5 \mathrm{~s}$, from 40 to 600 Da. The chemical components of VAC-EO were identified on the basis of their arithmetic retention indices on an Rtx-5MS capillary column under the same operating conditions used for GC-FID, relative to a homologous series of $n$-alkanes $\left(\mathrm{C}_{8}-\mathrm{C}_{20}\right)$ (Van Den Dool and Kratz 1963). The structures were computer-matched with the Wiley 7, NIST 08, and FFNSC 1.2 spectral libraries, and their fragmentation patterns were compared with literature data (Adams 2007).

\section{BACTERIAL STRAINS AND ANTIMICROBIAL ASSAYS}

The in vitro antimicrobial activity of VAC-EO was determined by minimum inhibitory concentration (MIC) assays based on the broth microdilution method (CLSI 2009). Streptococcus salivarius (ATCC 25975), Streptococcus sobrinus (ATCC 33478), Streptococcus mutans (ATCC 25175), Streptococcus mitis (ATCC 49456), Streptococcus sanguinis (ATCC 10556), Lactobacillus casei (ATCC 11578), and Enterococcus faecalis (ATCC 4082) were the standard strains used in the assay. Initially, the bacteria were transferred to blood agar (Difco Labs, Detroit, Mich, USA), and individual 24-h colonies were suspended in $10.0 \mathrm{~mL}$ of tryptic soy broth (Difco). A spectrophotometer (Femto, São Paulo, Brazil) at a wavelength $(\lambda)$ of $625 \mathrm{~nm}$ was used to standardize the suspensions of each microorganism, to match the transmittance of 81 , equivalent to 0.5 in the McFarland scale (1.5 $\left.\mathrm{x} 10^{8} \mathrm{CFU} / \mathrm{mL}\right)$. Dilution of the standardized suspension generated the final concentration of $5 \times 10^{5} \mathrm{CFU} / \mathrm{mL}$. VAC-EO was dissolved in DMSO (Merck, Darmstadt, Germany) at $16.0 \mathrm{mg}$ / $\mathrm{mL}$. Concentrations ranging from 4000 to $3.9 \mu \mathrm{g} /$ $\mathrm{mL}$ were achieved after dilution of VAC-EO in tryptic soy broth (Difco). After the dilutions, the concentrations of DMSO lay between $4 \%$ and $0.0039 \%(\mathrm{v} / \mathrm{v})$. Negative controls, three inoculated wells containing DMSO at concentrations ranging from $4 \%$ to $1 \%$, and one non-inoculated well free of antimicrobial agent were included. One inoculated well helped to test whether the broth was adequate for microorganisms to grow. The positive control was chlorhexidine dihydrochloride (CHD) (SigmaAldrich, St. Louis) at concentrations ranging from 5.9 to $0.115 \mu \mathrm{g} / \mathrm{mL}$, diluted in tryptic soy broth 
(Difco). The microplates (96-well) were sealed with parafilm and incubated at $37 \circ \mathrm{C}$ for $24 \mathrm{~h}$. After that, $30 \mathrm{~mL}$ of an aqueous solution of $0.02 \%$ resazurin (Sigma-Aldrich, St. Louis, MO, USA) was added into each microplate well to indicate the viability of the microorganism (Palomino et al. 2002). The lowest concentration of the sample that inhibited the growth of microorganism (MIC value) was determined as the lowest concentration of VAC-EO that was able to prevent the color of the resazurin solution from changing (Sarker et al. 2007). All the assays were conducted in triplicate.

\section{RESULTS}

CHEMICAL CONSTITUENTS OF THE ESSENTIAL OIL OF VITEX AGNUS-CASTUS (VAC-EO)

Vitex agnus-castus L. (Lamiaceae) leaves furnished a yellowish essential oil (VAC-EO) in $0.09 \pm 0.01$ $\%$ yield (w/w). Table I lists the 29 compounds identified in this oil. GC-FID and GC-MS analyses revealed that monoterpenes $(62.4 \%)$ were the main constituents of VAC-EO, whereas 1,8-cineole $(\mathbf{2}, 23.8 \%),(E)$ - $\beta$-farnesene $(\mathbf{5}, 14.6 \%),(E)$ caryophyllene $(4,12.5 \%)$, sabinene $(1,11.4 \%)$, and $\alpha$-terpinyl acetate $(3,7.7 \%)$ were the major constituents (Figure 1).

\section{ANTIMICROBIAL ACTIVITY OF VAC-EO}

The in vitro antibacterial activity (MIC values, see Table II) of VAC-EO was evaluated against a representative panel of cariogenic bacteria and compared the results with those obtained with chlorhexidine dihydrochloride (CHD, positive control). According to the literature, MIC values lower than $100 \mu \mathrm{g} / \mathrm{mL}$, between 100 and $500 \mu \mathrm{g} /$ $\mathrm{mL}$, and between 500 and $1000 \mu \mathrm{g} / \mathrm{mL}$ correspond to promising, moderate, and weak activities, respectively, whereas MIC values greater than $1000 \mu \mathrm{g} / \mathrm{mL}$ denote inactivity (Gibbons 2004, Rios and Recio 2005, Saleem et al. 2010). On the basis of these criteria, VAC-EO displayed moderate activity against Streptococcus salivarus, Streptococcus sanguinis and Enterococcus faecalis $(\mathrm{MIC}=200 \mu \mathrm{g} / \mathrm{mL})$, and Streptococcus sobrinus $(\mathrm{MIC}=125 \mu \mathrm{g} / \mathrm{mL})$. On the other hand, VACEO had promising activity against Streptococcus mutans $(\mathrm{MIC}=15.6 \mu \mathrm{g} / \mathrm{mL})$, Lactobacillus casei $(\mathrm{MIC}=15.6 \mu \mathrm{g} / \mathrm{mL})$, and Streptococcus mitis $(\mathrm{MIC}=31.25 \mu \mathrm{g} / \mathrm{mL})$.

\section{DISCUSSION}

The chemical composition of the essential oil extracted from Vitex agnus-castus collected in Egypt (Badawy and Abdelgaleil 2014), Turkey (Sarikurkcu et al. 2009, Duymuş et al. 2014), Morocco (Asdadi et al. 2015), Serbia (Stojković et al. 2011) and Brazil (Zoghbi et al. 1999) has been investigated previously. Although the content and composition of an essential oil may vary greatly among specimens collected from different places and in distinct seasons (Baser and Buchbauer

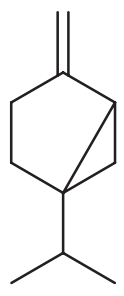

1

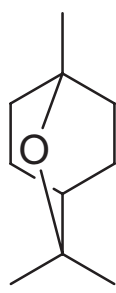

2

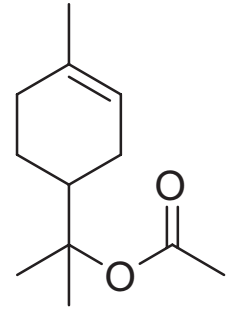

3

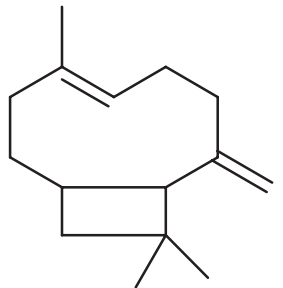

4

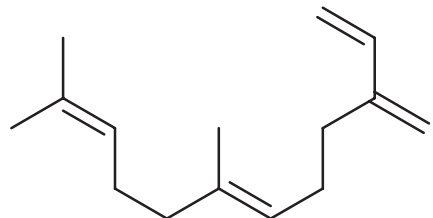

5

Figure 1 - Chemical structures of the monoterpenes sabinene (1), 1,8-cineole (2), $\alpha$-terpinyl acetate (3), (E)-caryophyllene (4), and (E)- $\beta$-farnesene (5) 
TABLE I

Chemical constituents of the essential oil of Vitex agnus-castus (VAC-EO).

\begin{tabular}{|c|c|c|c|c|}
\hline Compound & $\mathrm{RI}_{\text {exp }}{ }^{1}$ & $\mathbf{R I}_{\text {lit }}{ }^{2}$ & RA \% ${ }^{3}$ & Identification $^{4}$ \\
\hline$\alpha$-Thujene & 924 & 931 & 0.2 & RL MS \\
\hline$\alpha$-pinene & 931 & 939 & 5.9 & RL MS \\
\hline Sabinene & 971 & 976 & 11.4 & RL MS \\
\hline$\beta$-pinene & 977 & 980 & 0.9 & RL MS \\
\hline myrcene & 987 & 991 & 2.1 & RL MS \\
\hline 1-phellandrene & 1006 & 1139 & 0.6 & RL MS \\
\hline$\alpha$-terpinene & 1016 & 1018 & 0.3 & RL MS \\
\hline p-cymene & 1023 & 1026 & 0.2 & RL MS \\
\hline limonene & 1028 & 1031 & 2.8 & RL MS \\
\hline 1,8-cineole & 1031 & 1033 & 23.8 & RL MS \\
\hline (E)-b-ocimene & 1043 & 1050 & 0.6 & RL MS \\
\hline$\gamma$-terpinene & 1056 & 1062 & 0.7 & RL MS \\
\hline$\alpha$-terpinolene & 1084 & 1088 & 0.3 & RL MS \\
\hline Linalool & 1100 & 1098 & 0.2 & RL MS \\
\hline 4-terpineol & 1179 & 1177 & 2.0 & RL MS \\
\hline$\alpha$-terpineol & 1194 & 1189 & 2.1 & RL MS \\
\hline$\alpha$-terpinyl acetate & 1345 & 1352 & 7.7 & RL MS \\
\hline Citronellyl acetate & 1349 & 1354 & 0.6 & RL MS \\
\hline$\alpha$-gurjunene & 1402 & 1409 & 0.2 & RL MS \\
\hline (E)-caryophyllene & 1415 & 1418 & 12.5 & RL MS \\
\hline (E)- $\beta$-farnesene & 1452 & 1458 & 14.6 & RL MS \\
\hline Alloaromadendrene & 1454 & 1461 & 0.6 & RL MS \\
\hline Bicyclogermacrene & 1490 & 1494 & 6.6 & RL MS \\
\hline Sphatulenol & 1571 & 1576 & 0.4 & RL MS \\
\hline Caryophyllene oxide & 1575 & 1581 & 0.4 & RL MS \\
\hline Viridiflorol & 1588 & 1590 & 0.2 & RL MS \\
\hline$\alpha$-cadinol & 1650 & 1653 & 0.2 & RL MS \\
\hline Hydrocarbon monoterpenes & & & 26.0 & \\
\hline Oxygenated monoterpenes & & & 36.4 & \\
\hline Hydrocarbon sesquiterpenes & & & 34.5 & \\
\hline Oxygenated sesquiterpenes & & & 1.2 & \\
\hline Total & & & 98.1 & \\
\hline
\end{tabular}


TABLE II

Minimum inhibitory concentration (MIC) values $(\mu \mathrm{g} / \mathrm{mL})$ of the essential oil of Vitex agnus castus (VAC-EO) against selected cariogenic bacteria.

\begin{tabular}{lcc}
\hline Microorganisms & VAC-EO & Chlorhexidine $^{1}$ \\
\hline $\begin{array}{l}\text { Streptococcus mutans } \\
\text { (ATCC 25175) }\end{array}$ & 15.6 & 1.8 \\
$\begin{array}{l}\text { Streptococcus mitis } \\
\text { (ATCC 49456) }\end{array}$ & 31.25 & 14.7 \\
$\begin{array}{l}\text { Streptococcus sanguinis } \\
\text { (ATCC 10556) }\end{array}$ & 200 & 7.4 \\
$\begin{array}{l}\text { Streptococcus sobrinus } \\
\text { (ATCC 33478) }\end{array}$ & 125 & 1.8 \\
$\begin{array}{l}\text { Streptococcus salivarus } \\
\text { (ATCC 25975) }\end{array}$ & 200 & 7.4 \\
$\begin{array}{l}\text { Lactobacillus casei } \\
\text { (ATCC 11578) }\end{array}$ & 15.6 & 3.7 \\
$\begin{array}{l}\text { Enterococcus faecalis } \\
\text { (ATCC 4082) }\end{array}$ & 200 & 14.7 \\
\hline
\end{tabular}

${ }^{1}$ Chlorhexidine dihydrochloride (positive control).

2010), few constituents have been identified in the essential oils of Vitex agnus-castus other than the monoterpenes 1,8-cineole, sabinene, $\alpha$-pinene, and $\alpha$-terpinyl acetate and the sesquiterpenes $(E)$ - or $(Z)-\beta$-farnesene and $(E)$-caryophyllene. In the present study, we have detected 1,8-cineole, sabinene, $\alpha$-terpinyl acetate, $(E)$-caryophyllene, and $(\mathrm{Z})-\beta$-farnesene as the major constituents of VAC-EO. The chemical composition of VACEO is very similar to the chemical composition of the essential oil extracted from a $V$. agnuscastus specimen collected in the North of Brazil (Zoghbi et al. 1999). However, the content of $(E)$ caryophyllene is considerably higher in VAC-EO.

Some reports have explained that the lipophilicity of the chemical constituents of essential oils is associated with their antimicrobial activity. The main lipophilic components of these oils are monoterpenes and sesquiterpenes (Vieira et al. 2017). Lipophilicity allows the components of essential oils to diffuse across the cell membranes easily and then affect the metabolic pathways or organelles of microorganisms. Essential oils can also inhibit the syntheses of DNA, RNA, proteins, and polysaccharides in bacterial cells (Abad et al.
2012). The correlation between the lipophilicity of the constituents of an essential oil and the antimicrobial activity of the oil has motivated us to investigate the antibacterial activity of some essential oils against cariogenic bacteria (Aguiar et al. 2013a, Bardaji et al. 2015, Crevelin et al. 2015). In this study, it was found that VAC-EO displays promising activity against Streptococcus mutans $(\mathrm{MIC}=15.6 \mu \mathrm{g} / \mathrm{mL})$, Lactobacillus casei $(\mathrm{MIC}=$ $15.6 \mu \mathrm{g} / \mathrm{mL}$ ), and Streptococcus mitis (MIC $=31.25$ $\mu \mathrm{g} / \mathrm{mL}$ ). This is remarkable because $S$. mutans is one of the primary causative agents of dental caries, and its inhibition by natural compounds is unusual (Saleem et al. 2010).

The essential oils from different parts of $V$. agnus-castus have been reported to display antibacterial activity against Escherichia coli, Pseudomonas aeruginosa, Bacillus subtilis, and Staphylococcus aureus (Görler et al. 1985, Ekundayo et al. 1990). Previous studies have associated the antibacterial activity of the essential oils of Vitex sp. to the content of 1,8-cineole because the activity of the essential oil increases with increasing content of 1,8-cineole (Nyiligira et al. 2004). Once inside microbial cell, 1,8-cineole might interact with enzymes and proteins in the membrane to reverse the flow of protons, which would affect cellular activity (Stojković et al. 2011). However, 1,8-cineole alone does not present significant activity (MIC $>1000 \mu \mathrm{g} / \mathrm{mL}$, data not shown). In summary, the antimicrobial activity of VAC-EO may be correlated to other major components or even to minor chemicals that might underlie or even increase the activity of the major chemical constituents of this essential oil in a synergistic mechanism. However, although the antimicrobial activity of VAC-EO may be related to the lipophilicity of the monoterpenes thereof, the exact mechanism through which VAC-EO exerts its antimicrobial action is not clear and should be further investigated. 


\section{CONCLUSIONS}

The findings presented here highlight that the essential oil of Vitex agnus-castus leaves (VAC-EO) displays interesting and promising antimicrobial activity against some important cariogenic bacteria, including Streptococcus mutans. In this sense, VAC-EO might be used as a promising component of new oral care products because $S$. mutans is one of the main causative agents of oral disorders, such as dental caries. Further studies to identify the active chemical constituents of VAC$\mathrm{EO}$ and to determine its antimicrobial mechanism are underway.

\section{ACKNOWLEDGMENTS}

The authors thank the Brazilian foundations Fundação de Amparo à Pesquisa do Estado de São Paulo (FAPESP, grant no. 2007/54241-8), Fundação de Amparo à Pesquisa do Estado do Amazonas (FAPEAM), and Conselho Nacional de Desenvolvimento Científico e Tecnológico (CNPq) for grants and fellowships. We are also grateful to Izabel Cristina Casanova Turatti (FCFRP-USP) for the GC-FID and GC-MS analyses.

\section{REFERENCES}

ABAD MJ, BEDOYA LM, APAZA L AND BERMEJO P. 2012. The Artemisia L. genus: a review of bioactive essential oil. Molecules 17: 2542-2566.

ADAMS RP. 2007. Identification of essential oil components by gas chromatography/mass spectrometry. Carol Stream, IL: Allured Publishing Corporation, 804 p.

AGUIAR GP, CARVALHO CE, DIAS HJ, REIS EB, MARTINS MHG, WAKABAYASHI KAL, GROPPO M, MARTINS CHG, CUNHA WR AND CROTTI AEM. 2013a. Antimicrobial activity of selected essential oils against cariogenic bacteria. Nat Prod Res 27: 1668-1672.

AGUIAR GP ET AL. 2013b. Chemical composition and in vitro schistosomicidal activity of the essential oil from the flowers of Bidens sulphurea (Asteraceae). Nat Prod Res 27: 920-924.

ALVES JA, MANTOVANI ALL, MARTINS MHG, ABRAO F, LUCARINI R, CROTTI AEM AND MARTINS CHG. 2015. Antimycobacterial activity of some commercially available plant-derived essential oils. Chem Nat Prod 51: 353-355.

ASDADI A, HAMDOUCH A, OUKACHA A, MOUTAJ R, GHARBY S, HARHAR H, EL HADEK M, CHEBLI B AND IDRISSI-HASSANI LM. 2015. Study on chemical analysis, antioxidant and in vitro antifungal activities of essential oil from wild Vitex agnus-castus L. seeds growing in area of Argan tree of Morocco against clinical strains of Candida responsible for nosocomial infections. $\mathrm{J}$ Mycol Med 25: e118-127.

BADAWY MEI AND ABDELGALEIL SAM. 2014. Composition and antimicrobial activity of essential oils isolated from Egyptian plants against plant pathogenic bacteria and fungi. Ind Crops Prod 52: 776-782.

BALDIN ELL, AGUIAR GP, FANELA TLM, SOARES MCE, GROPPO M AND CROTTI AEM. 2015. Bioactivity of Pelargonium graveolens essential oil and related monoterpenoids against sweet potato whitefly, Bemisia tabaci biotype B. J Pest Sci 88: 191-199.

BARDAJI DKR, REIS EB, MEDEIROS TCT, CROTTI AEM AND MARTINS CHG. 2015. Antibacterial activity of commercially available plant-derived essential oils against oral pathogenic bacteria. Nat Prod Res 30: 1-4.

BASER KHC AND BUCHBAUER G. 2010. Handbook of essential oils - science, technology and applications. Boca Raton, FL: CRC Press, 976 p.

CLSI. 2009. Susceptibility testing of aerobic bacteria. Approved standard, $8^{\text {th }}$ ed., CLSI document M7-A8. Wayne, PA: NCCLS, 15 p.

CREVELIN EJ, CAIXETA SC, DIAS HJ, GROPPO M, CUNHA WR, MARTINS CHG AND CROTTI AEM. 2015. Antimicrobial activity of the essential oil of Plectranthus neochilus against cariogenic bacteria. Evid Based Complement Alternat Med 2015: Article ID 102317.

DUYMUŞ HG, ÇIFTÇI GA, YILDIRIM ŞU, DEMIRCI B AND KIRIMER N. 2014. The cytotoxic activity of Vitex agnus-castus L. essential oils and their biochemical mechanisms. Ind Crops Prod 55: 33-42.

EKUNDAYO O, LAAKSO I, HOLOPAINEN M, HILTUNEN R, OGUNTIMEIN B AND KAUPPINEN V. 1990. The chemical composition and antimicrobial activity of the leaf oil of Vitex agnus-castus L. J Essent Oil Res 2: 115-119.

GIBBONS S. 2004. Anti-staphylococcal plant natural products. Nat Prod Rep 2004: 263-277.

GÖRLER K, OEHLKE D AND SOICKE H. 1985. Iridoidführung von Vitex agnus-castus. Planta Med 51: 530-531.

GURMEET S AND CHHABRA KSK. 2011. Vitex agnuscastus - An overview. J Nat Remedies 11: 90-97.

MARI A, MONTORO P, PIZZA C AND PIACENTE S. 2012. Liquid chromatography tandem mass spectrometry determination of chemical markers and principal component analysis of Vitex agnus-castus L. fruits 
(Verbenaceae) and derived food supplements. J Pharm Biomed Anal 70: 224-230.

MELO NI, CARVALHO CE, FRACAROLLI L, CUNHA WR, VENEZIANI RCS, MARTINS CHG AND CROTTI AEM. 2015. Antimicrobial activity of the essential oil of Tetradenia riparia (Hochst.) Codd. (Lamiaceae) against cariogenic bacteria. Braz J Microbiol 46: 519-525.

NYILIGIRA E, VILJOEN AM, BAŞER KHC, ÓZEK T AND VAN VUUREN SF. 2004. Essential oil composition and in vitro antimicrobial and anti-inflammatory activity of South African Vitex species. South African J Bot 70: 611-617.

PALOMINO JC, MARTIN A, CAMACHO M, GUERRA H, SWINGS J AND PORTAELS F. 2002. Resazurin microtiter assay plate: simple and inexpensive method for detection of drug resistance in Mycobacterium tuberculosis. Chemotherapy 46: 2720-2722.

RIOS JL AND RECIO MC. 2005. Medicinal plants and antimicrobial activity. J Ethnopharmacol 100: 80-84.

SALEEM M, NAZIR M, ALI MS, HUSSAIN H, LEE YS, RIAZ N AND JABBAR A. 2010. Antimicrobial natural products: an update on future antibiotic drug candidates. Nat Prod Rep 27: 238-254.

SARIKURKCU C, ARISOY K, TEPE B, CAKIR A, ABALI G AND METE E. 2009. Studies on the antioxidant activity of essential oil and different solvent extracts of Vitex agnus-castus L. fruits from Turkey. Food Chem Toxicol 47: 2479-2483.

SARKER SD, NAHAR L AND KUMARASAMY Y. 2007. Microtitre platebased antibacterial assay incorporating resazurin as an indicator of cell growth, and its application in the in vitro antibacterial screening of phytochemicals. Methods 42: 321-324.

STOJKOVIĆ D, SOKOVIĆ M, GLAMOČLIJA J, DŽAMIĆ A, ĆIRIĆ A, RISTIĆ M AND GRUBIŠIĆ D. 2011. Chemical composition and antimicrobial activity of Vitex agnus-castus L. fruits and leaves essential oils. Food Chem 128: 1017-1022.

TONUCI LRS ET AL. 2012. In vitro schistosomicidal effects of the essential oil of Tagetes erecta. Rev Bras Farmacogn 22: 88-93.

VAN DEN DOOL H AND KRATZ PD. 1963. A generalization of the retention index system including linear temperature programmed gas-liquid partition chromatography. J Chromatogr 11: 463-471.

VIEIRA TM, DIAS HJ, MEDEIROS TCT, GRUNDMANN CO, GROPPO M, HELENO VCG, MARTINS CHG, CUNHA WR, CROTTI AEM AND SILVA EO. 2017. Chemical composition and antimicrobial activity of the essential oil of Artemisia absinthium (Asteraceae) leaves. J Essent Oil Bear P1 20: 123-131.

WAKABAYASHI KAL ET AL. 2015. Anthelmintic effects of the essential oil of Fennel (Apiacae) against Schistosoma mansoni. Chem Biodiv 12: 1105-1114.

ZAHID H, RIZWANI GH AND ISHAQE S. 2016. Phytopharmacological review on Vitex agnus-castus: a potential medicinal plant. Chinese Herb Med 8: 24-29.

ZOGHBI MGB, ANDRADE EH AND MAIA JGS. 1999. The essential oil of Vitex agnus-castus L. growing in the Amazon region. Flavour Frag J 14: 211-213. 